\title{
Mycotoxin production by Aspergillus niger aggregate strains isolated from harvested maize in three Portuguese regions
}

\author{
Célia Soares, Thalita Calado, Armando Venâncio* \\ IBB - Institute for Biotechnology and Bioengineering Centre of Biological Engineering, University of Minho, Braga, Portugal
}

\section{A R T I C L E I N F O}

\section{Article history:}

Received 15 November 2011

Accepted 4 May 2012

Available online 24 May 2012

\section{Keywords:}

Aspergillus niger

Maize

Fumonisin $\mathrm{B}_{2}$

Ochratoxin A

\section{Palabras clave:}

Aspergillus niger

Maíz

Fumonisina $B_{2}$

Ocratoxina A

\begin{abstract}
A B S T R A C T
Background: Maize is considered one of the crops more susceptible to mycotoxins in the world. Two of the mycotoxins commonly associated with maize are fumonisins and ochratoxin A. Aspergillus niger is a known producer of ochratoxin A and is easily found in maize. Recently, however, A. niger has been reported to produce as well fumonisins, mainly fumonisin $B_{2}$.

Aims: The aim of this study was to isolate $A$. niger strains from maize samples collected in three Portuguese maize growing regions and to detect the production of both fumonisin $\mathrm{B}_{2}$ and ochratoxin $\mathrm{A}$.

Methods: Ninety five maize samples were collected, plated, and all observable Aspergillus section Nigri strains were isolated. Strains were morphologically characterized and mycotoxin production was determined by HPLC-FD.

Results: Isolations resulted in a total of 270 strains of black Aspergillus from 73 samples ( $77 \%$ of the samples). About $14 \%$ of those strains were found to produce ochratoxin A and $39 \%$ of the strains were found to produce fumonisin $\mathrm{B}_{2}$.

Conclusions: An association between the production of these two mycotoxins could not be found and no conclusions could be taken whether the presence of $A$. niger aggregate strains will increase the risk of maize contamination with fumonisins and more specifically with fumonisin $B_{2}$.

(C) 2011 Revista Iberoamericana de Micología. Published by Elsevier España, S.L. All rights reserved.

\section{Producción de micotoxinas por aislamientos de Aspergillus niger procedentes de muestras de maíz recogido en tres regiones portuguesas}

\section{R E S U M E N}

Antecedentes: En todo el mundo se considera que el maíz es uno de los cereales más vulnerables a las micotoxinas. Dos de las asociadas con más frecuencia a este cereal son las fumonisinas y la ocratoxina A. Se sabe que $A$. niger produce ocratoxina A, que suele estar presente en el maíz. Sin embargo, recientemente, se ha descrito que $A$. niger puede producir fumonisinas, principalmente fumonisina $\mathrm{B}_{2}$.

Objetivos: El objetivo del presente estudio fue aislar las cepas de Aspergillus niger a partir de muestras de maíz provenientes de la siega en tres regiones agrícolas portuguesas y detectar la producción de fumonisina $\mathrm{B}_{2}$ y ocratoxina $\mathrm{A}$.

Métodos: Se obtuvieron 95 muestras de maíz de la siega en estas regiones, se sembraron en placas y se aislaron todas las cepas de Aspergillus sección Nigri observadas. Se caracterizaron morfológicamente las cepas y se determinó la producción de micotoxinas mediante cromatografía líquida de alto rendimiento con detección de fluorescencia.

Resultados: Se aislaron un total de 270 cepas de Aspergillus sección Nigri de 73 muestras (77\% de las muestras). Se observó que alrededor del 14\% de las cepas producían ocratoxina A, mientras que aproximadamente el $39 \%$ producían fumonisina $\mathrm{B}_{2}$.

Conclusiones: No pudo identificarse una asociación entre la producción de estas dos micotoxinas y no pudimos extraer conclusiones sobre si la presencia de cepas de A. niger aumentará el riesgo de contaminación del maíz por fumonisinas, en especial por fumonisina $\mathrm{B}_{2}$.

(C) 2011 Revista Iberoamericana de Micología. Publicado por Elsevier España, S.L. Todos los derechos reservados.

\footnotetext{
* Corresponding author.

E-mail address: avenan@deb.uminho.pt (A. Venâncio).
} 
Maize (Zea mays L.) constitutes one of the most important crops worldwide, being, however, a good substrate for growth, development and activity of filamentous fungi. ${ }^{13,32}$ Maize is associated with a large number of fungal species belonging to the genders of Aspergillus, Fusarium, and Penicillium that can cause spoilage and mycotoxin contamination. ${ }^{17,26}$ Toxin-producing fungi can invade food at pre-harvest period, harvest-time or post-harvest during storage. Colonization and eventual contamination may occur in the same stage or a later one. ${ }^{18}$ Concerns about mycotoxin occurrence in maize are usually associated to Aspergillus flavus, for its ability to produce aflatoxins, and to Fusarium verticillioides and Fusarium proliferatum, for the production of fumonisins. ${ }^{7}$ Other fungi associated with this commodity are the ochratoxigenic ones. ${ }^{41}$ In a recent survey, ochratoxin A (OTA) was detected in $70 \%$ of maize bread samples, from the central zone of Portugal. From these, one sample exceeded the European maximum limit established for OTA in cereal products for human consumption $\left.\left(3 \mu \mathrm{g} \mathrm{kg}^{-1}\right)\right)^{8,15} \mathrm{The}$ presence of OTA in maize has also been associated with the contamination of beer, ${ }^{30}$ belonging the main Aspergillus OTA producer species to the $A$. niger aggregate. ${ }^{33}$

A. niger has a great economical and biotechnological interest and is extensively used for production of extracellular enzymes and organic acids such as citric acid. ${ }^{5,37}$ A. niger has even been granted the GRAS (Generally Regarded As Safe) status in certain industrial production processes by the Food and Drug Administration of the US government. ${ }^{35}$

The discovery of $A$. niger strains producing OTA by Abarca et al. ${ }^{1}$ raised concerns not only for their biotechnological safety but also for their food safety risk, due to their common presence in different commodities. ${ }^{10,14,20}$ OTA is a potent nephrotoxin and has teratogenic, immunosuppressive and carcinogenic properties. ${ }^{11}$ Cereals and cereal based food and feed are the main contributors to OTA intake in humans and animals, since OTA is stable under normal food processing operation conditions and it is carried-over from raw materials to processed products. ${ }^{24}$ Recently, however, these concerns may have widened. There are several reports stating that A. niger can also produce fumonisin $\mathrm{B}_{2}\left(\mathrm{FB}_{2}\right)$ along with OTA. ${ }^{9,19,27}$ Fumonisins are suspected to cause human and animal toxicoses and are regarded as carcinogenic. ${ }^{12}$ Of the seven fumonisins currently identified, fumonisins $\mathrm{B}_{1}\left(\mathrm{FB}_{1}\right), \mathrm{B}_{2}\left(\mathrm{FB}_{2}\right)$ and $\mathrm{B}_{3}\left(\mathrm{FB}_{3}\right)$ are the most frequently detected in fungal cultures or in naturally contaminated maize. ${ }^{31}$ What concerns Aspergillus niger aggregate strains, the main fumonisin produced is the $\mathrm{FB}_{2}$, and reports show that $\mathrm{FB}_{2}$ production by these species is higher while growing in low water activity $\left(a_{\mathrm{w}}\right)$ culture media, ${ }^{28}$ when comparing with its production by Fusarium species. Therefore, maize and other commodities with low $a_{\mathrm{w}}$ may be more susceptible to $\mathrm{FB}_{2}$ contamination in the presence of $A$. niger aggregate species.

The aim of this study was to evaluate the $\mathrm{FB}_{2}$ and OTA production by $A$. niger aggregate strains isolated from maize grains of three Portuguese regions.

\section{Materials and methods}

\section{Chemicals}

OTA standard was supplied by Biopure (Austria). A standard solution of OTA was prepared in the OTA vial purchased from Biopure. The stock solution was made in $4 \mathrm{~mL}$ toluene:acetic acid (99:1) at $250 \mu \mathrm{g} \mathrm{ml}^{-1}$, and stored at $-20^{\circ} \mathrm{C}$. An intermediate standard solution was prepared at $250 \mathrm{ng} \mathrm{ml}^{-1}$ by dilution with the same solvent, and stored at $-20^{\circ} \mathrm{C}$.

Fumonisin $B_{2}$ standard was supplied by Sigma Chemical Co. (St. Louis, MO, USA) at $5 \mathrm{mg} \mathrm{ml}^{-1}$. An intermediate standard solution was prepared at $5 \mu \mathrm{g} \mathrm{ml}^{-1}$ by dilution in acetonitrile:distilled water (50:50), and stored at $-20^{\circ} \mathrm{C}$.

All solvents employed were of glass distilled or HPLC grade and all reagents used were of analytical grade.

\section{Sampling plan}

The survey was carried out in three center-south Portuguese regions, from north to south: Beira Litoral, Ribatejo, and Alto Alentejo. Beira Litoral region (center west) climate is transitional between Atlantic and Mediterranean with annual precipitation of $984 \mathrm{~mm}$ and the annual average temperatures are very moderate, $14.6^{\circ} \mathrm{C}$. In higher areas the annual precipitation can easily exceed $1000 \mathrm{~mm}$. Ribatejo (central west) climate is temperate south-Mediterranean. The annual average temperatures are very moderate, $15^{\circ} \mathrm{C}$ with an annual precipitation of about $500-600 \mathrm{~mm}$. The region of Alentejo (center-southeast) has a Mediterranean climate feature of continental, i.e. hot and dry. The average annual temperature exceeds $17^{\circ} \mathrm{C}$, and in the summer temperatures above $30^{\circ} \mathrm{C}$ are recorded throughout the eastern region. Average annual precipitation is less than $600 \mathrm{~mm}$.

Thirty-two samples were taken in Beira Litoral region, forty samples from the Ribatejo and twenty three from Alto Alentejo, making a total of ninety five samples being taken in three distinct stages of the storage chain. Samples were collected into paper bags to prevent water condensation with the indication of the date, water content and transported to the laboratory within 24 hours.

Twenty samples were taken at reception with a water content between 19 and 22\%, 42 samples were taken after drying with a water content between 14 and 15\% and 33 samples were taken after storage with a water content between 10 and $14 \%$, between the months of November of 2008 and April of 2009 (Table 1).

\section{Isolation of fungi}

Fifteen grains of each maize sample were plated in Petri dishes with MEA10 (containing per liter: malt extract $20 \mathrm{~g}$; peptone $1 \mathrm{~g}$; glucose $20 \mathrm{~g}$; agar $20 \mathrm{~g}$; sodium chloride $100 \mathrm{~g}$ ) for 7 days at $25^{\circ} \mathrm{C}$. All Aspergillus section Nigri strains were isolated after observing the plates under a stereomicroscope. The strains were purified by transferring them to Malt Extract agar (MEA; containing per liter: malt extract $20 \mathrm{~g}$, glucose $20 \mathrm{~g}$, peptone $1 \mathrm{~g}$, agar $20 \mathrm{~g}$ ) and incubating for 7 days at $25^{\circ} \mathrm{C}$. Identification of the isolates was carried out by morphological characterization following the taxonomic keys and guides available for the Aspergillus genus. ${ }^{16,36}$ The taxonomy of fungi belonging to the section Nigri comprises one of the most confusing and complex due to the subtle differences between the species. In this manner, some biseriate species, such as Aspergillus carbonarius and Aspergillus ibericus can be recognized through the larger conidia size (6-8 $\mu \mathrm{m})$, for instance, and the uniseriate species (Aspergillus aculeatus, Aspergillus japonicus and Aspergillus uvarum), can be easily recognized through the absence of metullae. On the other hand, colonies representative of $A$. niger aggregate are very difficult to distinguish morphologically. In this study, because molecular analysis was not carried out, all black biseriate aspergilli strains other than A. carbonarius, Aspergillus ellipticus and A. ibericus

Table 1

Number of samples taken at reception, dryer and storage.

\begin{tabular}{lcccc}
\hline Region & \multicolumn{3}{c}{ Storing stage } & Total \\
\cline { 2 - 4 } & Reception & Dryer & Storage & \\
\hline Beira Litoral & 0 & 22 & 10 & 32 \\
Ribatejo & 10 & 10 & 20 & 40 \\
Alentejo & 10 & 10 & 3 & 23 \\
Total & 20 & 42 & 33 & 95 \\
\hline
\end{tabular}


will be referred to as the $A$. niger aggregate. Fungal frequency at each region was calculated as the ratio between the number of isolates and the number of samples taken. Fungal incidence was determined as the percentage of samples where the fungus was isolated.

\section{HPLC-FD}

OTA samples were analysed by HPLC-FD with a Jasco FP-920 fluorescence detector (333 nm excitation wavelength; $460 \mathrm{~nm}$ emission wavelength). Chromatographic separations were performed on a reverse phase C18 column YMC-Pack ODS-AQ $(250 \mathrm{~mm} \times 4.6 \mathrm{~mm}$ ID, $5 \mu \mathrm{m})$ fitted with a precolumn with the same stationary phase. The mobile phase was water:acetonitrile:methanol $(99: 99: 2, \mathrm{v} / \mathrm{v})$ pumped at $0.8 \mathrm{ml}$ $\mathrm{min}^{-1}$. The injection volume was $30 \mu \mathrm{l}$.

$\mathrm{FB}_{2}$ samples were analysed by HPLC-FD with a Jasco FP920 fluorescence detector ( $460 \mathrm{~nm}$ excitation wavelength; $500 \mathrm{~nm}$ emission wavelength). Chromatographic separations were performed on a reverse phase C18 column YMC-Pack ODS-AQ $(250 \mathrm{~mm} \times 4.6 \mathrm{~mm} \mathrm{ID,} 5 \mu \mathrm{m})$, fitted with a precolumn with the same stationary phase. The mobile phase was acetonitrile: water:acetic acid (60:40:1, v/v) pumped at $1.0 \mathrm{ml} \mathrm{min}^{-1}$. The injection volume was $30 \mu l$.

\section{Mycotoxin production}

\section{OTA production}

Strains were tested for OTA production in Yeast Extract Sucrose (YES) agar medium (containing per liter: yeast extract $20 \mathrm{~g}$, sucrose $150 \mathrm{~g}$, agar $15 \mathrm{~g}$ ). Strains were inoculated on $6 \mathrm{~cm}$ diameter plates and incubated at $25^{\circ} \mathrm{C}$ for 7 days in the dark. Extraction methodology consisted in removing 3 agar plugs (mean 3 agar plug weight of $0.424 \mathrm{~g}$ ) from one colony and placing into a $4 \mathrm{ml}$ vial where $1 \mathrm{ml}$ of methanol was added. After 60 minutes, the extract was filtered through $0.45 \mu \mathrm{m}$ filters, evaporated and further dissolved in $1 \mathrm{ml}$ of mobile phase as described by Bragulat et al. ${ }^{6}$

Samples were taken as positive for each of the toxins when a peak was obtained at a retention time similar to each standard, with a height five times higher than the baseline noise. Limit of detection (LOD) was of $0.7 \mathrm{ng} \mathrm{ml}^{-1}$.

OTA production values were converted to $\mu \mathrm{g} \mathrm{kg}^{-1}$ using the mean agar plugs value.

\section{Fumonisin $B_{2}$ production}

All strains were tested for fumonisin $B_{2}$ production in Czapek Yeast Autolysate (CYA) agar (containing per liter: sucrose $30 \mathrm{~g}$, Difco yeast extract $5 \mathrm{~g}, \mathrm{~K}_{2} \mathrm{HPO}_{4} 1 \mathrm{~g}, \mathrm{NaNO}_{3} 3 \mathrm{~g}, \mathrm{KCl} 0.5 \mathrm{~g}, \mathrm{MgSO}_{4} \cdot 7 \mathrm{H}_{2} \mathrm{O}$ $0.5 \mathrm{~g}, \mathrm{FeSO}_{4} \cdot 7 \mathrm{H}_{2} \mathrm{O} 0.01 \mathrm{~g}, \mathrm{ZnSO}_{4} \cdot 7 \mathrm{H}_{2} \mathrm{O} 0.01 \mathrm{~g}, \mathrm{CuSO}_{4} \cdot 5 \mathrm{H}_{2} \mathrm{O} 0.005 \mathrm{~g}$, agar $20 \mathrm{~g}$ ). Strains were inoculated on $6 \mathrm{~cm}$ diameter plates and incubated at $25^{\circ} \mathrm{C}$ for 7 days in the dark. Extraction and derivatization methodology as described in Abrunhosa et al. ${ }^{2}$ was employed: 5 agar plugs (mean 5 agar plug weight of $0.707 \mathrm{~g}$ ) were removed from one colony, and placed into a $4 \mathrm{ml}$ vial, where $1 \mathrm{ml}$ of methanol:water (75:25) was added. After sonication for 50 minutes, the extract was filtered through $0.45 \mu \mathrm{m}$ filters, evaporated and further derivatized with $200 \mu$ l of methanol, $200 \mu \mathrm{l}$ of borate buffer, $100 \mu \mathrm{l}$ of sodium cyanide and $100 \mu \mathrm{l}$ of NDA.

Samples were taken as positive for each of the toxins when a peak was obtained at a retention time similar to each standard, with a height five times higher than the baseline noise. LOD was of $75 \mathrm{ng} \mathrm{ml}^{-1}$.

$\mathrm{FB}_{2}$ production values were converted to $\mu \mathrm{g} \mathrm{kg}^{-1}$ using the mean agar plugs value.

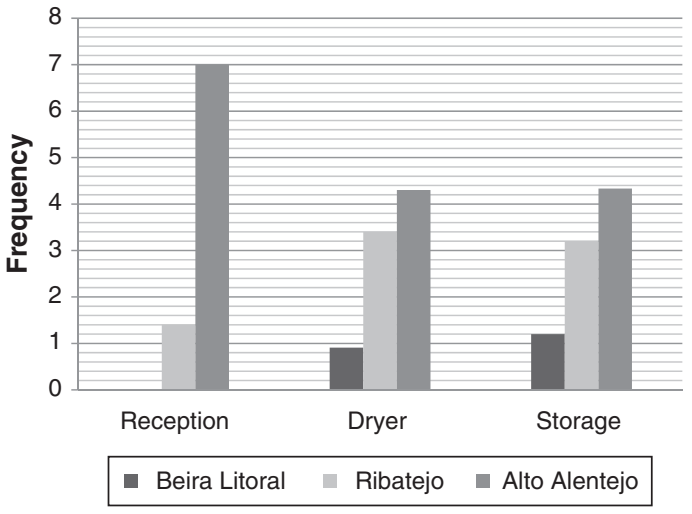

Fig. 1. Aspergillus section Nigri frequency at each region per storing stage.

\section{Association between $\mathrm{OTA}$ and $\mathrm{FB}_{2}$ production}

To estimate the possible association between OTA and $\mathrm{FB}_{2}$ production, a $2 \times 2$ contingency table test was used. ${ }^{4}$ A low association between variables is indicated when $P h i$ is close to 0 , and a strong association is indicated when $P h i$ is close to 1 . Statistical analyses were performed using SPSS Statistics version 19.0.

\section{Results}

\section{Isolation of black Aspergillus}

From the ninety five samples of maize grains obtained in the three Portuguese regions, Aspergillus section Nigri isolates were found in seventy three samples (77\%). From these, two hundred and seventy strains were isolated (Table 2). Morphological analysis revealed that all were bisseriate and within the $A$. niger aggregate; uniseriate species and other bisseriate species, such as $A$. carbonarius or A. ibericus, were not isolated. The incidence of Aspergillus section Nigri differed among regions being present in $59 \%, 80 \%$ and $96 \%$ of the samples from Beira Litoral, Ribatejo and Alto Alentejo, respectively. Fungal frequency followed the same trend, being higher in Alto Alentejo, in all stages, than in the other regions. Beira Litoral is the region that exhibits the lowest frequency (Fig. 1).

\section{Mycotoxin production}

In Aspergillus section Nigri strains isolated from maize, OTA and $\mathrm{FB}_{2}$ were produced by $14 \%$ and $39 \%$ of the isolates, respectively (Table 3). Thirty-seven OTA producer strains and $105 \mathrm{FB}_{2}$ producer strains were isolated. Beira Litoral exhibits the lowest incidence of ochratoxigenic strains (6\%) and the highest incidence of $\mathrm{FB}_{2}$ strains (50\%); Ribatejo has the highest incidence of ochratoxigenic strains $(18 \%)$ and the smallest incidence of $\mathrm{FB}_{2}$ producers (34\%); while Alto Alentejo has a mean incidence of OTA (12\%) and $\mathrm{FB}_{2}(38 \%)$ producing strains.

To evaluate if there is an association between the production of OTA and $\mathrm{FB}_{2}$, the Phi association value was calculated (Table 3). For

Table 2

Number of isolates and samples from three Portuguese regions.

\begin{tabular}{lll}
\hline Region & $\begin{array}{l}\text { Number of samples with } \\
\text { isolations per total of } \\
\text { samples (mean frequency) }\end{array}$ & $\begin{array}{l}\text { Number of Aspergillus } \\
\text { niger aggregate isolates } \\
\text { (mean incidence) }\end{array}$ \\
\hline Beira Litoral & $19 / 32(59 \%)$ & $32(1.0)$ \\
Ribatejo & $32 / 40(80 \%)$ & $111(2.8)$ \\
Alto Alentejo & $22 / 23(96 \%)$ & $127(5.5)$ \\
Total & $73 / 95(77 \%)$ & $270(2.8)$ \\
\hline
\end{tabular}


Table 3

Mycotoxin production of Aspergillus niger aggregate isolated in three Portuguese regions.

\begin{tabular}{|c|c|c|c|c|c|c|}
\hline \multirow[t]{2}{*}{ Region } & \multicolumn{2}{|c|}{ OTA } & \multicolumn{2}{|c|}{$\mathrm{FB}_{2}$} & \multirow[t]{2}{*}{$P h i$} & \multirow[t]{2}{*}{$p$-Value } \\
\hline & Negative & Positive & Negative & Positive & & \\
\hline Beira Litoral & 30 & 2 & 16 & 16 & 0.000 & 1.000 \\
\hline Ribatejo & 92 & 20 & 71 & 41 & -0.064 & 0.499 \\
\hline Alto Alentejo & 111 & 15 & 78 & 48 & 0.065 & 0.466 \\
\hline Total & 233 & 37 & 165 & 105 & -0.009 & 0.888 \\
\hline
\end{tabular}

Table 4

Mean values of OTA and $\mathrm{FB}_{2}$ production $\left(\mu \mathrm{g} \mathrm{kg}{ }^{-1}\right)$ by Aspergillus niger aggregate isolated in three Portuguese regions

\begin{tabular}{|c|c|c|c|c|}
\hline Region & OTA $\left(\mu \mathrm{g} \mathrm{kg}^{-1}\right)$ & Mean levels ${ }^{\mathrm{a}}\left(\mu \mathrm{g} \mathrm{kg}^{-1}\right)$ & $\mathrm{FB}_{2}\left(\mu \mathrm{g} \mathrm{kg}^{-1}\right)$ & Mean levels ${ }^{\mathrm{a}}\left(\mu \mathrm{g} \mathrm{kg}^{-1}\right)$ \\
\hline Beira Litoral & $6-20$ & 13 & $1-2323$ & 477 \\
\hline Ribatejo & $1-18$ & 6 & $1-3536$ & 524 \\
\hline Alto Alentejo & $1-18$ & 6 & $1-5382$ & 366 \\
\hline
\end{tabular}

a Mean values were determined taking into consideration only the producing strains.

Table 5

Number of $A$. niger aggregate strains producing $\mathrm{OTA}$ and $\mathrm{FB}_{2}$ and its distribution in three Portuguese regions.

\begin{tabular}{|c|c|c|c|c|c|}
\hline \multirow[t]{2}{*}{ Region } & \multirow[t]{2}{*}{ No. strains tested } & \multirow[t]{2}{*}{ No. OTA producing strains $\left(0.8-18 \mu \mathrm{g} \mathrm{kg}^{-1}\right)$} & \multicolumn{3}{|c|}{ No. of strains that produce $\mathrm{FB}_{2}$} \\
\hline & & & $<100 \mu \mathrm{g} \mathrm{kg}^{-1}$ & $100-1000 \mu \mathrm{g} \mathrm{kg}^{-1}$ & $>1000 \mu \mathrm{g} \mathrm{kg}^{-1}$ \\
\hline Beira Litoral & 34 & 2 & 5 & 9 & 2 \\
\hline Ribatejo & 121 & 20 & 19 & 15 & 7 \\
\hline Alto Alentejo & 132 & 15 & 28 & 12 & 8 \\
\hline
\end{tabular}

the overall results the Phi - association value is fair $(P h i<0.1)$, and not significant $(p>0.05)$, meaning that their production is independent from each other.

As expected the OTA production by these strains is relatively low in all regions (Table 4 ), with production values ranging between $1 \mu \mathrm{g} \mathrm{kg}^{-1}$ and $20 \mu \mathrm{g} \mathrm{kg}^{-1}\left(0.4 \mathrm{ng} \mathrm{ml}^{-1}\right.$ and $\left.8.5 \mathrm{ng} \mathrm{ml}^{-1}\right)$. The $\mathrm{FB}_{2}$ production is much higher and ranged between $1 \mu \mathrm{g} \mathrm{kg}^{-1}$ and $5382 \mu \mathrm{g} \mathrm{kg}^{-1}$. Regarding OTA, even though Beira Litoral exhibits the lowest amount of producing isolates, the production mean for OTA is the highest when comparing with Ribatejo and Alto Alentejo. The same does not apply to $\mathrm{FB}_{2}$, being Ribatejo the region with the highest production mean. The region with higher amount of isolates, Alto Alentejo, is the one with lower production means.

$\mathrm{FB}_{2}$ production varied between strains where almost $50 \%$ produce below $100 \mu \mathrm{g} \mathrm{kg}^{-1}$, 34\% produce between 100 and $1000 \mu \mathrm{g} \mathrm{kg}^{-1}$, and $16 \%$ produce at levels above $1000 \mu \mathrm{g} \mathrm{kg}^{-1}$ (Table 5).

\section{Discussion}

\section{Isolation of Aspergillus section Nigri}

Morphological analysis revealed that all isolated strains were bisseriate and within the Aspergillus niger aggregate. Uniseriate species were not found in these maize samples, even though it had been previously isolated from Nigerian and Argentinean maize. ${ }^{1,23}$ Also in other study, with Portuguese wine grapes, uniseriate strains were rarely isolated ( 2 isolates in 770 isolated strains), ${ }^{40}$ and only in a grape growing area located northern from these maize growing areas.

Aspergillus section Nigri species are common soil inhabitants contaminating ripening crops in Mediterranean, tropical and subtropical regions ${ }^{21}$ being more resistant to higher solar exposure and higher temperatures. Therefore, the higher incidence of isolates in Ribatejo and in Alto Alentejo (Table 2) may be explained by the fact that both these regions have Mediterranean climates, very hot and dry during summer time, frequently achieving temperatures around $40^{\circ} \mathrm{C}$. Beira Litoral, on the other hand, has Atlantic influences with more moderate temperatures and higher precipitation, being more common other fungal species. The black aspergilla presence in Portuguese regions with Mediterranean climate had already been assessed in a survey of ochratoxigenic fungi in Portuguese wine grapes ${ }^{39,40}$ where these species have been isolated from $22 \%$ of grape samples. Although the sampling sites were not the same, it was also possible to observe a higher incidence in Alto Alentejo (72-100\%) than in Ribatejo (18-48\%). ${ }^{39}$ In these studies, temperature and relative humidity were found to determine the relative incidence of Aspergillus section Nigri in grapes.

\section{Mycotoxin production by fungi}

The production of OTA within Aspergillus section Nigri varies according to different authors: from $3 \%$ to $28 \%$, being extreme value up to $80 \%$ reported in the literature, as reviewed by Palumbo et al. ${ }^{34}$ In the previous Portuguese study concerning the production of OTA from strains isolated from grapes, percentages of OTA producing strains of $A$. niger aggregate were lower (4\%). ${ }^{40}$ However, OTA producing strains were not equally distributed among all regions, being the incidence in Southern regions higher. ${ }^{38}$ Magnoli et al. 23 reported $6 \%$ of ochratoxigenic $A$. niger strains in previously disinfected Argentinean maize kernels, which lies within the value obtained from Portuguese grapes and maize.

The number of fumonigenic $A$. niger aggregate strains is slightly higher (36\%) in comparison with similar studies in grapes where $23 \%$ and $29 \%$ of Aspergillus niger aggregate strains produced $\mathrm{FB}_{2} \cdot{ }^{3,42}$ However, the values are much lower than in other studies in grapes and coffee beans $19,27,29$ where $60-70 \%$ of the isolates were found to produce $\mathrm{FB}_{2}$ although in these cases a very low number of strains were tested.

It is clear the $A$. niger species can produce both OTA and $\mathrm{FB}_{2}$; however, it was not clear if there is an association between the productions of these two mycotoxins. Although statistically not significant, the distribution of OTA and $\mathrm{FB}_{2}$ producing strains among regions seems to indicate that there is no connection between the production of both these toxins by the same fungus. 
OTA production values $\left(0.4 \mu \mathrm{gl}^{-1}\right.$ to $\left.8.5 \mu \mathrm{gl}^{-1}\right)$ are lower than the ones reported by Magnoli et al. ${ }^{24}$ which ranged between $2 \mu \mathrm{gl}^{-1}$ and $24.5 \mu \mathrm{gl}^{-1}$. The $\mathrm{FB}_{2}$ production is much higher and ranged between $1 \mu \mathrm{g} \mathrm{kg}^{-1}$ and $5382 \mu \mathrm{g} \mathrm{kg}^{-1}$, being lower, however, than the ones obtained by Mogensen et al. ${ }^{27}$ that ranged between $229 \mu \mathrm{g} \mathrm{kg}^{-1}$ and $6476 \mu \mathrm{g} \mathrm{kg}^{-1}$ and by Susca et al. ${ }^{42}$ that ranged between $100 \mu \mathrm{g} \mathrm{kg}^{-1}$ and $293,000 \mu \mathrm{g} \mathrm{kg}^{-1}$. The requirements for $\mathrm{FB}_{2}$ production by Aspergillus and Fusarium strains are not the same. Fusarium spp. are predominantly considered as field fungi and except under extreme conditions, the concentrations of fumonisins produced by Fusarium spp. do not increase during grain storage. ${ }^{25}$ However, Aspergillus have the ability to grow and produce mycotoxins at lower water availability conditions. ${ }^{22}$ Although the optimum temperature and $a_{w}$ differ, the levels produced under optimum condition are of the same order of magnitude. ${ }^{28}$

The fact that Aspergillus section Nigri fungi are associated to commodities not previously associated with Fusarium and, consequently, with fumonisins, the production of $\mathrm{FB}_{2}$ by Aspergillus section Nigri strains may extend the concern about fumonisins to a wider range of commodities.

In conclusion, Aspergillus section Nigri strains isolated from maize can produce both OTA and $\mathrm{FB}_{2}$ but, being maize a well-known natural substrate for Fusarium species and their fumonisins, it is still unclear if the presence of black aspergilla will increase the risk of maize contamination with fumonisins.

\section{Conflict of interest}

The authors declare no conflict of interest.

\section{Acknowledgements}

Célia Soares and Thalita Calado were supported by grants from Fundação para a Ciência e Tecnologia (references SFRH/BD/37264/2007 and SFRH/BD/79364/2011, respectively).

The authors are grateful for the support and cooperation of the National Producers Association of Maize and Sorghum (ANPROMIS - Associação Nacional de Produtores de Milho e de Sorgo).

\section{References}

1. Abarca ML, Bragulat MR, Castellá G, Cabañes FJ. Ochratoxin A production by strains of Aspergillus niger var. niger. Appl Environ Microb. 1994;60:2650-2.

2. Abrunhosa L, Calado T, Resende T, Venâncio A. A fluorescence-LC method with NDA pre-column derivatization for fumonisins determination in black aspergilli cultures. J Liq Chromatogr Related Technol. 2011;34:1594-603.

3. Abrunhosa L, Calado $T$, Venâncio A. Incidence of fumonisin $B_{2}$ production by Aspergillus niger in Portuguese wine regions. J Agric Food Chem. 2011;59:7514-8

4. Asuero AG, Sayago A, González AG. The correlation coefficient: an overview. Crit Rev Anal Chem. 2006;36:41-59.

5. Baker SE. Aspergillus niger genomics: past, present and into the future. Med Mycol. 2006;44:S17-21.

6. Bragulat MR, Abarca ML, Cabañes FJ. An easy screening method for fungi producing ochratoxin A in pure culture. Int J Food Microbiol. 2001;71:139-44.

7. Chulze SN. Strategies to reduce mycotoxin levels in maize during storage: a review. Food Addit Contam. 2010;27:651-7.

8. Commission Regulation (EC) No. 1881/2006. Setting maximum levels for certain contaminants in foodstuff; 2006

9. Frisvad JC, Smedsgaard JJ, Samson RA, Larsen TO, Thrane U. Fumonisin B 2 production by Aspergillus niger. J Agric Food Chem. 2007;55:9727-32.

10. Gautam AK, Sharma S, Avasthi S, Bhadauria R. Diversity, pathogenicity and toxicology of A. niger: an important spoilage fungi. Res J Microbiol. 2011;6:270-80.

11. International Agency for Research on Cancer (IARC). Some naturally occurring substances; food items and constituents, heterocyclic aromatic amines and mycotoxins. IARC monographs on the evaluation of carcinogenic risks to humans, vol. 56; 1993. p. 489.

12. International Agency for Research on Cancer (IARC). Fumonisins $B_{1}$ and $B_{2}$ and fusarin C. Toxins derived from Fusarium moniliforme, vol. 56; 1993. p. 1445.
13. Janardhana GR, Raveesha KA, Shetty HS. Mycotoxin contamination of maize grains grown in Karnataka (India). Food Chem Toxicol. 1999;37:863-8.

14. Joosten HMLJ, Goetz J, Pittet A, Schellenberg M, Bucheli P. Production of ochratoxin A by Aspergillus carbonarius on coffee cherries. Int J Food Microbiol. 2001;65:39-44.

15. Juan C, Pena A, Lino C, Moltó JC, Mañes J. Levels of ochratoxin A in wheat and maize bread from the central zone of Portugal. Int J Food Microbiol. 2008;127:284-9.

16. Klich MA. Identification of common Aspergillus species. Netherlands: CBS; 2002

17. Kumar V, Basu MS, Rajendran TP. Mycotoxin research and mycroflora in some commercially important agricultural commodities. Crop Prot. 2008;27: 891-905.

18. Logrieco A, Bottalico A, Mulé G, Moretti A, Perrone G. Epidemiology of toxigenic fungi and their associated mycotoxins for some Mediterranean crops. Eur J Plant Pathol. 2003;109:645-67.

19. Logrieco A, Ferracane R, Haidukowsky M, Cozzi G, Visconti A, Ritieni A. Fumonisin $B_{2}$ production by Aspergillus niger from grapes and natural occurrence in must. Food Addit Contam Part A. 2009;26:1495-500.

20. Lucchetta G, Bazzo I, Dal Cortivo G, Stringher L, Bellotto D, Borgo M, et al Occurrence of black Aspergilli and ochratoxin A on grapes in Italy. Toxins. 2010;2:840-55.

21. Magan N, Aldred D. Conditions of formation of ochratoxin A in drying, transport and in different commodities. Food Addit Contam Part A. 2005;22:10-6.

22. Magan N, Lacey J. Effect of temperature and $\mathrm{pH}$ on water relations of field and storage fungi. Trans Br Mycol Soc. 1984;82:71-81.

23. Magnoli C, Hallak C, Astoreca A, Ponsone L, Chiacchiera S, Dalcero AM. Occurrence of ochratoxin A-producing fungi in commercial corn kernels in Argentina. Mycopathologia. 2006;161:53-8.

24. Magnoli CE, Astoreca AL, Chiacchiera SM, Dalcero AM. Occurrence of ochratoxin $A$ and ochratoxigenic mycoflora in corn and corn based foods and feeds in some South American countries. Mycopathologia. 2007;163:249-60.

25. Marín S, Magan N, Ramos AJ, Sanchis V. Fumonisin producing strains of Fusarium: a review of their ecophysiology. J Food Prot. 2004;67:1792-805.

26. Marín S, Sanchis V, Arnau F, Ramos AJ, Magan N. Colonisation and competitiveness of Aspergillus and Penicillium species on maize grain in the presence of Fusarium moniliforme and Fusarium proliferatum. Int J Food Microbiol 1999;45:107-17.

27. Mogensen JM, Frisvad JC, Thrane U, Nielsen KF. Production of fumonisin $B_{2}$ and $\mathrm{B}_{4}$ by Aspergillus niger on grapes and raisins. J Agric Food Chem. 2010;58: 954-8.

28. Mogensen J, Nielsen K, Samson R, Frisvad JC, Thrane U. Effect of temperature and water activity on the production of fumonisins by Aspergillus niger and different Fusarium species. BMC Microbiol. 2009;9:281-92.

29. Noonim P, Mahakarnchanakul W, Nielsen KF, Frisvad JC, Samson RA. Fumonisin $\mathrm{B}_{2}$ production by Aspergillus niger in Thai coffee beans. Food Addit Contam Part A. 2009;26:94-100.

30. Odhav B, Naicker V. Mycotoxins in South African traditionally brewed beers Food Addit Contam. 2002;19:55-61.

31. Orsi RB, Corrêa B, Possi CR, Schammass EA, Nogueira JR, Dias SMC, et al. Mycoflor and occurrence of fumonisins in freshly harvested and stored hybrid maize. Stored Prod Res. 2000;36:75-87

32. Oyebanji AO, Efiuvweywere BJO. Growth of spoilage mould and aflatoxins $B_{1}$ production in naturally contaminated or artificially inoculated maize as influenced by moisture content under ambient tropical condition. Int Biodeter Biodegr. 1999;44:209-17.

33. Palencia ER, Hinton DM, Bacon CW. The black Aspergillus species of maize and peanuts and their potential for mycotoxin production. Toxins. 2010;2:300-416.

34. Palumbo JD, O'Keeffe TL, Vasquez SJ, Mahoney NE. Isolation and identification of ochratoxin A-producing Aspergillus section Nigri strains from California raisins. Lett Appl Microbiol. 2011;52:330-6.

35. Perrone G, Susca A, Cozzi G, Ehrlich K, Varga J, Frisvad JC, et al. Biodiversity of Aspergillus species in some important agricultural products. Stud Mycol. 2007;59:53-66.

36. Pitt JI, Hocking AD, editors. Fungi and food spoilage. 3rd ed. New York, USA: Springer; 2009

37. Schuster E, Dunn-Coleman N, Frisvad JC, van Dijck PWM. On the safety of Aspergillus niger - a review. Appl Microbiol Biotechnol. 2002;59:426-35.

38. Serra R. Microflora das uvas portuguesas e seu potencial para a contaminação das uvas com micotoxinas, com destaque para a ocratoxina A. PhD thesis, Universidade do Minho; 2005.

39. Serra R, Abrunhosa L, Kozakiewicz Z, Venâncio A. Black Aspergillus species as ochratoxin A producers in Portuguese wine grapes. Int J Food Microbiol. 2003;88:63-8.

40. Serra R, Braga A, Venâncio A. Mycotoxin-producing and other fungi isolated from grapes for wine production, with particular emphasis on ochratoxin A. Res Microbiol. 2005;156:515-21.

41. Shotwell OL, Hesseltine CW, Gouldeno ML. Ochratoxin A: occurrence as natura contaminant of a corn sample. Appl Microbiol. 1969;5:765-6.

42. Susca A, Proctor RH, Mule G, Stea G, Ritieni A, Logrieco A, et al. Correlation of mycotoxin fumonisin $B_{2}$ production and presence of the fumonisin biosynthetic gene fum8 in Aspergillus niger from grape. J Agric Food Chem. 2010;58: 9266-72. 